\title{
Analisis Gas Terlarut pada Minyak Isolasi sebagai Indikator Kegagalan Transformator Daya dengan Metode Dissolved Gas Analysis
}

\author{
Misto, Haryono \\ Universitas Jember, J1. Kalimantan No. 37 Jember 68121 Indonesia \\ (tlp: 0331-330224; fax: 0331-337422) \\ e-mail: unmuh.haryo@gmail.com
}

\begin{abstract}
ABSTRAK
Transformator daya merupakan peralatan utama dan yang paling penting dalam sistem penyaluran tenaga listrik. Sistem operasional pada transformator daya ini terdapat permasalahan yang umum terjadi seperti kegagalan thermal dan kegagalan elektris. Kegagalan thermal dan elektris umumnya menghasilkan fault gas. Minyak isolasi pada transformator daya selain sebagai pendingin juga berfungsi melarutkan gas-gas akibat kegagalan thermal dan kegagalan elektris. Informasi mengenai adanya indikasi kegagalan pada transformator dapat diperoleh dari hasil identifikasi jenis dan jumlah konsentrasi gas yang terlarut dalam minyak, atau biasa disebut dengan metode Dissolved Gas Analysis (DGA). Metode DGA dapat dilakukan dengan Total Dissolved Combustible Gas (TDCG), Key Gas, Roger's Ratio, Ratio $\mathrm{CO}_{2} / \mathrm{CO}$, dan Duval's Triangle yang sesuai dengan IEEE std. C57-104.1991 dan IEC 60599. TDCG juga dapat digunakan untuk menentukan jadwal pengujian DGA. Berdasarkan analisis yang telah dilakukan, Transformator Daya II Gardu Induk Tanggul pada tahun 2011,2012 dan 2013 dengan metode TDCG transformator dalam kondisi 2, Key Gas diperoleh CO sebagai gas kunci dengan indikasi kegagalan overheating cellulose, Ratio $\mathrm{CO}_{2} / \mathrm{CO}$ menunjukkan proses pemburukan sedang terjadi pada isolasi kertas akibat kegagalan high thermal dengan temperature $>200^{\circ} \mathrm{C}$, Roger's Ratio terjadi Thermal fault dengan temperature $150-300^{\circ} \mathrm{C}$ dan Duval's Triangle berada di luar kriteria evaluasi dan jadwal pengujian DGA selanjutnya adalah tiga bulanan.
\end{abstract}

Kata kunci: Transformator Daya, Minyak Transformator, Fault Gas, Dissolved Gas Analysis, Gas Terlarut.

Copyright $@ 2019$ Universitas Muhammadiyah Jember.

\section{PENDAHULUAN}

Transformator daya merupakan peralatan utama dan peralatan yang paling penting dalam sistem penyaluran tenaga listrik. Hal tersebut dikarenakan transformator daya memiliki fungsi sebagai penyalur daya listrik dan mentransformasikan dari tegangan tinggi ke tegangan menengah atau sebaliknya. Oleh karena itu perlu dipastikan keadaannya selalu dalam kondisi baik, sehingga tidak terjadi suatu masalah yang dapat mengganggu kesinambungan sistem penyaluran tenaga listrik. Pemantuan kondisi transformator daya dapat dilakukan dengan suatu pengujian kandungan gas terlarut, atau yang dinamakan uji Dissolved Gas Analysis (DGA). Informasi mengenai adanya indikasi kegagalan pada transformator dapat diperoleh dari hasil identifikasi jenis dan jumlah konsentrasi gas yang terlarut dalam minyak.

Penelitian ini menggunakan metode DGA. Selain itu, peneliti merancang suatu perangkat lunak yang dapat mempermudah penggunaan metode DGA dalam hal pembuatan laporan mengenai pengujian DGA dan membuat jadwal pengujian selanjutnya pada transformator. Obyek yang dianalisis pada penelitian ini adalah transformator daya II 150/20 KV PT. PLN (persero) APP Probolinggo Gardu Induk Tanggul. Sedangkan untuk perancangan aplikasi menggunakan bahasa pemrograman VB.6.

\section{KAJIAN PUSTAKA}

\subsection{Transformator Tenaga}

Transformator daya adalah suatu peralatan listrik yang memiliki fungsi untuk menyalurkan daya atau tenaga dari tegangan tinggi ke tegangan menengah atau sebaliknya. Transformator menyalurkan daya menggunakan prinsip hukum lorentz dan faraday. Hal ini dimana arus bolak 
balik yang mengalir mengelilingi suatu inti besi yang kemudian berubah menjadi magnet. Magnet yang dikelilingi oleh belitan, maka akan terjadi perbedaan potensial terhadap kedua ujung belitan tersebut. Transformator tenaga dapat dilihat pada gambar 1 dibawah ini.

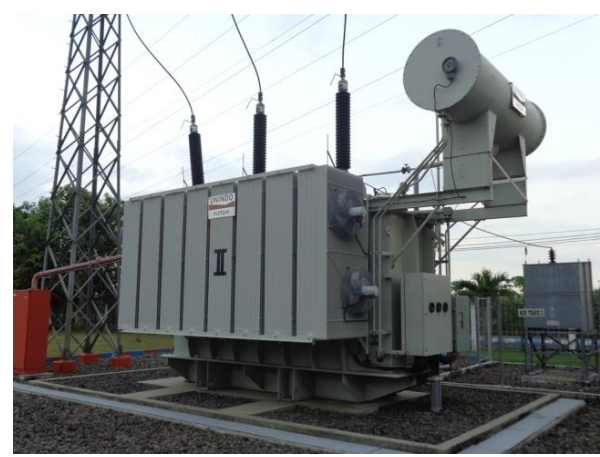

Gambar 1. Transformator Tenaga

\subsection{Bagian-bagian Transformator Tenaga}

Bagian-bagian pada transformator tenaga terdapat bagian utama dan peralatan buntu, yang diantaranya adalah:

a. Bagian Utama

- Inti besi

- Kumparan transformator

- Minyak transformator

- Bushing

- Tangki konservator

\section{b. Peralatan Buntu}

- Pendingin transformator

- Tap changer

- Alat pernapasan atau breather

- Indikator

\subsection{Minyak Isolasi Transformator}

Sistem isolasi merupakan suatu peralatan yang paling vital dalam teknik tegangan tinggi. Apabila sistim isolasi pada sebuah peralatan buruk, maka akan berdampak pada operasi peralatan tersebut. Terdapat dua bagian penting di dalam transformator sistim isolasi, yaitu kertas selulosa dan minyak isolasi. Kertas isolasi transformator memiliki fungsi sebagai isolasi, pemberi jarak, dan memiliki kemampuan mekanis. Sedangkan minyak isolasi memiliki fungsi utama pada transformator, antara lain:

a. Sebagai media isolasi, baik antar belitan maupun belitan dengan body trafo

b. Sebagai media pendingin belitan trafo

c. Sebagai media pemadam saat terjadi arcing

d. Sebagai media pelarut gas hasil dari proses pemburukan minyak dan isolasi kertas

\subsection{Gas Terlarut pada Minyak Transformator}

Timbulnya gas terlarut dalam transformator adalah seringkali merupakan indikasi awal dari suatu gangguan yang mungkin terjadi. Faktor yang dapat menimbulkan gangguan tersebut seperti besarnya kandungan air, kandungan asam, dll.

Keberadaan gas propana $\left(\mathrm{C}_{2} \mathrm{H}_{8}\right)$, propilen $\left(\mathrm{C}_{3} \mathrm{H}_{6}\right)$ dan butana $\left(\mathrm{C}_{4} \mathrm{H}_{8}\right)$ tidak termasuk gas yang punya pengaruh penting pada transformator, meskipun gas tersebut dapat dideteksi dan 
diidentifikasi pada pengujian gas terlarut. Sedangkan gas yang termasuk gas yang mudah terbakar (combustible gas) antara lain adalah hidrogen $\left(\mathrm{H}_{2}\right)$, metana $\left(\mathrm{CH}_{4}\right)$, etana $\left(\mathrm{C}_{2} \mathrm{H}_{6}\right)$, etilen $\left(\mathrm{C}_{2} \mathrm{H}_{4}\right)$, asetilen $\left(\mathrm{C}_{2} \mathrm{H}_{2}\right)$, karbon dioksida $\left(\mathrm{CO}_{2}\right)$ dan karbon monoksida $\left(\mathrm{C}_{\mathrm{O}}\right)$.

\subsection{Dissolved Gas Analysis (DGA)}

Dissolved Gas Analysis (DGA) dapat diartikan sebagai test darah pada transformator. Darah manusia adalah suatu senyawa yang mudah untuk melarutkan zat lain yang berada di dalam tubuh. Melalui pengujian zat-zat terlarut pada darah, maka akan diperoleh informasi terkait dengan kesehatan manusia. Begitu pula dengan transformator, pengujian zat terlarut seperti gas pada minyak transformator akan memberikan informasi terkait akan kondisi transformator tersebut. Pengujian DGA dilakukan pada suatu sampel minyak diambil dari unit transformator. Uji DGA memiliki kelebihan dan kekurangan. Kelebihan pada uji DGA adalah dapat mendeteksi sedini mungkin terhadap kegagalan yang terjadi pada transformator yang diuji. Sedangkan kekurangan pada uji DGA adalah dibutuhkan tingkat kemurnian yang tinggi terhadap sampel minyak yang diuji.

\subsection{Langkah Pengujian DGA}

Pengambilan data dan pengujian dilakukan berdasarkan pada metode ASTM D 3613. Tahapan yang harus dilakukan untuk pengambilan data adalah sebagai berikut:
a. Pengambilan sampel
b. Ekstraksi gas dari minyak
c. Analisis gas untuk mengevaluasi
d. Pengambilan kesimpulan

\section{METODE PENELITIAN}

\subsection{Metode Pengolahan Data}

Metode pengolahan data yang digunakan dalam penelitian ini mengacu pada standar analisis DGA yang sesuai dengan IEEE std. C57-104.1991 dan IEC 60599. Adapun diagram mengenai alir analisis hasil uji DGA dapat dilihat pada gambar 2 dibawah ini.

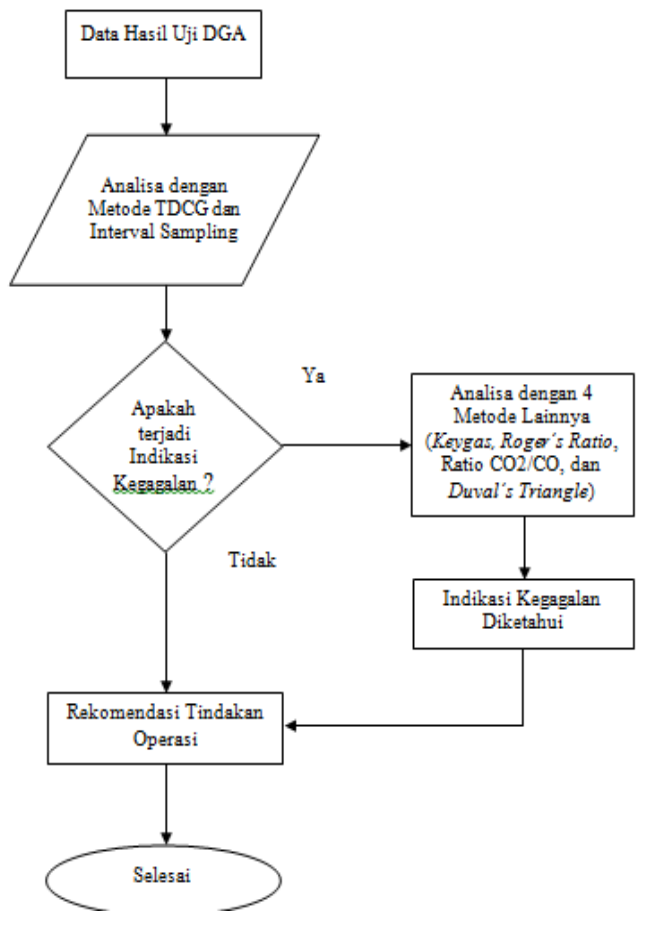

Gambar 2. Diagram Alir Analisis Hasil Uji DGA 


\subsection{Obyek Analisis Data}

Adapun obyek analisis data pada penelitian ini dapat dilihat pada tabel 1 berikut.

Tabel 1. Data Transformator II Gardu Induk Tanggul

\begin{tabular}{ll}
\hline Gardu Induk & Gardu Induk Tanggul \\
\hline No. Transformator & II \\
Merk & UNINDO ALSTOM \\
Tipe & TTUB 150 / 60.000 \\
No. Seri & P 60 LEC 303-01 \\
Vektor Grup & YNyn0[D1] \\
Arus & $231 / 1732 \mathrm{~A}$ \\
Tegangan Kerja & $150 / 20 \mathrm{kV}$ \\
Daya & 60 MVA \\
Impedansi & $12,10 \%$ \\
Jenis Minyak & SHELL DIALA B \\
Jumlah Minyak & 21 ton \\
Jumlah Tap & 18 \\
Tahun Operasi & 8 Desember 2003 \\
Tahun Pembuatan & 2003 \\
\hline
\end{tabular}

Berikut adalah data hasil uji DGA minyak Transformator Daya II pada PT. PLN (Persero) P3B Jawa Bali-APP Probolinggo-Gardu Induk Tanggul:

Tabel 2. Data Hasil Uji DGA Transformator II Gardu Induk Tanggul

\begin{tabular}{lccccccccc}
\hline No & Tanggal Uji & $\mathbf{H}_{2}$ & $\mathbf{C o}$ & $\mathbf{C H}_{4}$ & $\mathbf{C O}_{\mathbf{2}}$ & $\mathbf{C 2 H}_{\mathbf{4}}$ & $\mathbf{C 2 H}_{\mathbf{6}}$ & $\mathbf{C}_{2} \mathbf{H}_{2}$ & TDCG \\
1 & 16 Juli 2008 & 20 & 5,25 & 0 & 1918,69 & 0 & 17 & 12,45 & $\mathbf{5 4 , 7}$ \\
2 & 7 Okt. 2009 & 20 & 0 & 148,75 & 2106,97 & 0 & 114,97 & 0 & $\mathbf{2 8 3 , 7 2}$ \\
3 & 27 Nov. 2010 & 57,82 & 140,25 & 76,71 & 3143,11 & 1,77 & 29,87 & 0 & $\mathbf{3 0 6 , 4 1}$ \\
4 & 9 Maret 2011 & 42,58 & 529,13 & 43,55 & 2421,52 & 2,23 & 2,29 & 0 & $\mathbf{6 1 9 , 8 9}$ \\
5 & 25 Mei 2012 & 96,84 & 709,69 & 85,65 & 2646,84 & 0 & 19,29 & 1,63 & $\mathbf{9 1 3 , 1}$ \\
6 & 28 Mei 2013 & 100,23 & 803,09 & 76,35 & 2979,85 & 0 & 0 & 0 & $\mathbf{9 7 9 , 6 7}$ \\
\hline
\end{tabular}

\subsection{Standar IEEE (TDCG)}

Metode analisis yang pertama adalah Total Dissolved Combustible Gas (TDCG). Tabel 3. Data Hasil Uji DGA Transformator II Gardu Induk Tanggul

\begin{tabular}{ccccccccc}
\hline Kondisi & $\mathbf{H}_{2}$ & $\mathbf{C o}$ & $\mathbf{C H}_{4}$ & $\mathbf{C O}_{2}$ & $\mathbf{C 2 H}_{4}$ & $\mathbf{C}_{2} \mathbf{H}_{6}$ & $\mathbf{C}_{2} \mathbf{H}_{2}$ & TDCG \\
\hline X1 & $0-100$ & $0-350$ & $0-120$ & $0-2500$ & $0-50$ & $0-64$ & $0-35$ & $\mathbf{0 - 7 2 0}$ \\
X2 & $101-$ & $121-$ & $121-$ & $2501-$ & $51-$ & $66-100$ & $36-50$ & $\mathbf{7 2 1 -}$ \\
& 700 & 400 & 400 & 4000 & 100 & & & $\mathbf{1 9 2 0}$ \\
X3 & $701-$ & $571-$ & $401-$ & $4001-$ & $101-$ & $101-$ & $51-80$ & $\mathbf{1 9 2 1 -}$ \\
& 1800 & 1400 & 1000 & 10000 & 200 & 150 & & $\mathbf{4 6 3 0}$ \\
X4 & $>1800$ & $>1400$ & $>1000$ & $>10000$ & $>200$ & $>150$ & $>80$ & $>\mathbf{4 6 3 0}$ \\
\hline
\end{tabular}

$* \mathrm{CO}_{2}$ tidak termasuk TDCG

Tabel 4. Kondisi Transformator Daya

\begin{tabular}{ccl}
\hline Kondisi & Konsentrasi & Diagnosa \\
\hline Kondisi 1 & $0-720$ & Normal \\
Kondisi 2 & $721-1920$ & Tingkat TDCG mulai tinggi \\
Kondisi 3 & $1921-4630$ & Waspada dekomposisi isolasi \\
Kondisi 4 & $>4630$ & Kerusakan isolasi \\
\hline
\end{tabular}

\subsection{Gas Kunci (Key Gas)}

Gas kunci merupakan gas yang terbentuk pada transformator berpendingin minyak yang dapat digunakan untuk menentukan jenis kegagalan. Tabel 5 berikut merupakan jenis kegagalan menurut analisis gas kunci. 
Tabel 5. Jenis Kegagalan Gas Kunci

\begin{tabular}{|c|c|c|c|}
\hline Fault & Key Gas & Criteria & Gas Perccent \\
\hline Arcing & $\begin{array}{l}\text { Acetylene } \\
\left(\mathrm{C}_{2} \mathrm{H}_{2}\right)\end{array}$ & $\begin{array}{l}\text { Large amount of } \mathrm{H}_{2} \text { and } \mathrm{C}_{2} \mathrm{H}_{2} \text {, and } \\
\text { minor quantities of } \mathrm{CH}_{4} \text { and } \mathrm{C}_{2} \mathrm{H}_{4} \\
\mathrm{CO} \text { and } \mathrm{CO}_{2} \text { may also exist if } \\
\text { cellulose is involved. }\end{array}$ & $\begin{array}{l}\mathrm{H}_{2}: 60 \% \\
\mathrm{C}_{2} \mathrm{H}_{2}: 30 \%\end{array}$ \\
\hline $\begin{array}{l}\text { Corona } \\
\text { (Low } \\
\text { Energy PD) }\end{array}$ & $\begin{array}{l}\text { Hydrogen } \\
\left(\mathrm{H}_{2}\right)\end{array}$ & $\begin{array}{l}\text { Large amount of } \mathrm{H}_{2} \text {, some } \mathrm{CH}_{4} \text {, } \\
\text { with small quantities of } \mathrm{C}_{2} \mathrm{H}_{6} \text { and } \\
\mathrm{C}_{2} \mathrm{H}_{4}, \mathrm{CO} \text { and } \mathrm{CO}_{2} \text { may be } \\
\text { comparable if cellulose is involved. }\end{array}$ & $\begin{array}{l}\mathrm{H}_{2}: 85 \% \\
\mathrm{CH}_{4}: 13 \%\end{array}$ \\
\hline $\begin{array}{l}\text { Overheating } \\
\text { Of Oil }\end{array}$ & $\begin{array}{l}\text { Ethylene } \\
\left(\mathrm{C}_{2} \mathrm{H}_{4}\right)\end{array}$ & $\begin{array}{l}\text { Large amount of } \mathrm{C}_{2} \mathrm{H}_{4} \text { less amount } \\
\mathrm{C}_{2} \mathrm{H}_{6} \text { some quantities of } \mathrm{CH}_{4} \text { and } \\
\mathrm{H}_{2} \text {. }\end{array}$ & $\begin{array}{l}\mathrm{C}_{2} \mathrm{H}_{4}: 63 \% \\
\mathrm{C}_{2} \mathrm{H}_{6}: 20 \%\end{array}$ \\
\hline $\begin{array}{l}\text { Overheating } \\
\text { of Cellulose }\end{array}$ & $\begin{array}{l}\text { Carbon } \\
\text { Monoxide } \\
(\mathrm{CO})\end{array}$ & $\begin{array}{l}\text { Large amount of } \mathrm{CO} \text { and } \mathrm{CO}_{2} \\
\text { Hydrocarbon gases may exist. }\end{array}$ & $\mathrm{CO}: 92 \%$ \\
\hline
\end{tabular}

\subsection{Roger's Ratio}

Analisis yang ketiga adalah Roger's Ratio. Analisis pada Roger's Ratio dapat dilihat pada tabel 6 berikut ini.

Tabel 6. Jenis Kegagalan Gas Kunci

\begin{tabular}{|c|c|c|c|c|c|}
\hline \multicolumn{2}{|c|}{ Range Code Rasio } & $\underline{\mathrm{C}_{2} \mathrm{H}_{2}}$ & $\mathrm{CH}_{4}$ & $\underline{\mathrm{C}_{2} \mathrm{H}_{4}}$ & \multirow{6}{*}{ Masalah yang terjadi } \\
\hline & $<0.1$ & $\mathbf{0}$ & 1 & $\mathbf{0}$ & \\
\hline & $0.1-1$ & 1 & $\mathbf{0}$ & $\mathbf{0}$ & \\
\hline & $\mathbf{1}-\mathbf{3}$ & 1 & 2 & 1 & \\
\hline & $>\mathbf{3}$ & 2 & 2 & 2 & \\
\hline Kasus & Tipe Gangguan & \multicolumn{3}{|c|}{ Kode } & \\
\hline 0 & No Fault & 0 & 0 & 0 & Normal \\
\hline 1 & $\begin{array}{l}\text { Low Energy Partial } \\
\text { Discharge }\end{array}$ & 1 & 1 & 0 & $\begin{array}{l}\text { Terjadi pelepasan muatan yang terjadi } \\
\text { disebabkan udara yang terjebak dalam } \\
\text { sistem isolasi atau minyak mengandung } \\
\text { banyak kadar air. }\end{array}$ \\
\hline 2 & $\begin{array}{l}\text { High Energy Partial } \\
\text { Discharge }\end{array}$ & 1 & 1 & 0 & $\begin{array}{l}\text { Sama seperti diatas, tetapi lebih } \\
\text { disebabkan oleh perforasi dari isolasi padat } \\
\text { yang diakibatkan oleh sparking atau } \\
\text { arching biasanya menimbulkan gas } \mathrm{CO} \\
\text { dan } \mathrm{CO}_{2}\end{array}$ \\
\hline 3 & $\begin{array}{c}\text { Low Energy Partial } \\
\text { Discharge, Sparking } \\
\text { Arching }\end{array}$ & $1-2$ & 0 & $1-2$ & $\begin{array}{l}\text { Sparking terus menerus disebabkan oleh } \\
\text { kontak yang jelek atau sistem grounding } \\
\text { yang jelek, menurunnya nilai dielektrik } \\
\text { dari minyak. }\end{array}$ \\
\hline 4 & $\begin{array}{l}\text { High Energy Partial } \\
\text { Discharge, Arching }\end{array}$ & 1 & 0 & 2 & $\begin{array}{l}\text { Terjadi loncatan bunga api antara belitan } \\
\text { dengan belitan, atau belitan dengan } \\
\text { grounding. }\end{array}$ \\
\hline 5 & $\begin{array}{l}\text { Thermal Fault Less } \\
\text { than } 150^{\circ} \mathrm{C}\end{array}$ & 0 & 0 & 1 & $\begin{array}{l}\text { Isolasi kawat penghantar mengalami } \\
\text { overheating. }\end{array}$ \\
\hline 6 & $\begin{array}{l}\text { Thermal Fault } \\
\text { Temp } 150-300^{\circ} \mathrm{C}\end{array}$ & 0 & 2 & 0 & $\begin{array}{l}\text { Overheating pada inti trasformator, } \\
\text { hubungan singkat pada lapisan inti, eddy }\end{array}$ \\
\hline 7 & $\begin{array}{l}\text { Thermal Fault } \\
\text { Temp } 300-700^{\circ} \mathrm{C}\end{array}$ & 0 & 2 & 1 & $\begin{array}{l}\text { current, kontak jelek pada terminal, terjadi } \\
\text { sirkulasi arus inti trasformator dengan }\end{array}$ \\
\hline 8 & $\begin{array}{l}\text { Thermal Fault } \\
\text { Temp over } 700^{\circ} \mathrm{C}\end{array}$ & 0 & 2 & 2 & ground. \\
\hline
\end{tabular}

\subsection{Ratio $\mathrm{CO}_{2} / \mathrm{CO}$}

Metode analisis yang keempat adalah Ratio $\mathrm{CO}_{2} / \mathrm{CO}$. Rasio ini digunakan untuk mendeteksi keterlibatan isolasi kertas pada fenomena kegagalan. Berikut adalah tabel ratio $\mathrm{CO}_{2} / \mathrm{CO}$ : 
Tabel 7. Analisis Metode Ratio $\mathrm{CO}_{2} / \mathrm{CO}$

\begin{tabular}{lcl}
\hline RATIO & NILAI & Keterangan Isolasi Kertas \\
\hline $5-<10$ & $\begin{array}{l}\text { Normal } \\
\text { Indikasi proses pemburukan sedang } \\
\text { terjadi pada isolasi kertas akibat } \\
\text { kegagalan high thermal } \\
\text { Ada indikasi yang kuat akan } \\
\text { terjadinya kegagalan elektrik } \\
\mathrm{CO}_{2} / \mathrm{CO}\end{array}$ & $\begin{array}{l}\text { sehinga menimbulkan karbonasi } \\
\text { pada kertas. } \\
\text { Adanya kegagalan thermal pada } \\
\text { isolasi kertas pada belitan. }\end{array}$ \\
\hline
\end{tabular}

\subsection{Duval's Triangle}

Metode ini digunakan untuk mengetahui jenis kerusakan secara umum dari suatu transformator yang bermasalah. Metode ini bukan digunakan untuk menentukan suatu transformator bermasalah atau tidak.

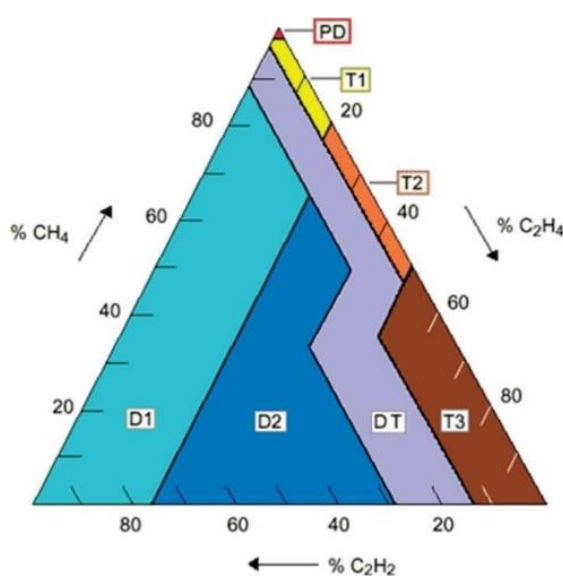

Gambar 3. Segitiga Duval

\section{ANALISIS DAN PEMBAHASAN}

\subsection{Analisis Hasil Uji DGA}

Berdasarkan data hasil uji DGA Transformator II Gardu Induk Tanggul maka dapat dianalisis sebagai berikut:

\section{a. Metode TDCG}

Berdasarkan studi kasus yang telah dilakukan terhadap Transformator II Gardu Induk Tanggul, terdapat dua buah data hasil uji DGA dimana TDCG nilainya berada diantara 721-1920 ppm yaitu pada Tahun 2012 sebesar 913,1 ppm dan Tahun 2013 sebesar 979,67.

Tabel 8. Hasil Pengujian dengan Metode TDCG

\begin{tabular}{cccccccccc}
\hline No & Tgl Uji & $\mathbf{H}_{\mathbf{2}}$ & $\mathbf{C O}$ & $\mathbf{C H}_{\mathbf{4}}$ & $\mathbf{C O}_{2}$ & $\mathbf{C}_{2} \mathbf{H}_{\mathbf{4}}$ & $\mathbf{C}_{2} \mathbf{H}_{\mathbf{6}}$ & $\mathbf{C}_{2} \mathbf{H}_{2}$ & TDCG \\
\hline 1 & 16 Juli 2008 & 20 & 5.25 & 0 & 1918.69 & 0 & 17 & 12.45 & 54.7 \\
2 & 07 Okt. 2009 & 20 & 0 & 148.75 & 2106.97 & 0 & 114.97 & 0 & 283.72 \\
3 & 27 Nov. 2010 & 57.82 & 140.25 & 76.71 & 3143.11 & 1.77 & 29.87 & 0 & 306.41 \\
4 & 9 Maret 2011 & 42.58 & 529.13 & 43.55 & 2421.52 & 2.23 & 2.29 & 1.63 & 619.89 \\
5 & 25 Mei 2012 & 96.84 & 709.69 & 85.65 & 2646.84 & 0 & 19.29 & 1.63 & 913.1 \\
6 & 28 Mei 2013 & 100.23 & 803.09 & 76.35 & 2979.85 & 0 & 0 & 0 & 979.67 \\
\hline
\end{tabular}


b. Menentukan Jadwal Pengujian Minyak

Dari data hasil uji DGA tabel 9 dapat kita ketahui bahwa transformator dalam pada Tahun 2012 dan 2013 dalam kondisi 2 berdasarkan dengan TDCG sebesar 979,67 ppm dan 913,1 ppm.

Tabel 9. Hasil Perhitungan Penjadwalan Sampel Minyak

\begin{tabular}{|c|c|c|c|c|}
\hline \multirow[b]{2}{*}{$\begin{array}{c}\text { Kondisi } \\
1\end{array}$} & \multirow{2}{*}{$\begin{array}{l}\text { Tingkat TDCG } \\
\text { atau nilai } \\
\text { tertinggi dari } \\
\text { masing-masing } \\
\text { gas (dari tabel } \\
\text { diatas) }\end{array}$} & \multirow{2}{*}{$\begin{array}{c}\text { Tingkat } \\
\text { kenaikan } \\
\text { TDCG } \\
\text { (ppm } \\
\text { perhari) }\end{array}$} & \multicolumn{2}{|c|}{$\begin{array}{l}\text { Interval sampling dan tindakan } \\
\text { pengoperasian }\end{array}$} \\
\hline & & & $\begin{array}{l}\text { Interval } \\
\text { Sampling }\end{array}$ & Tindakan Pengoperasian \\
\hline \multirow{3}{*}{$\begin{array}{l}\text { Kondisi } \\
2\end{array}$} & \multirow{3}{*}{$\begin{array}{c}721-1920 \\
\text { ppm,atau nilai } \\
\text { tertinggi dari } \\
\text { masing-masing } \\
\text { Gas }\end{array}$} & $<10$ & $\begin{array}{c}\text { Tiga } \\
\text { bulanan }\end{array}$ & \multirow{3}{*}{$\begin{array}{l}\text { Perhatikan, analisis } \\
\text { penyebab masing- } \\
\text { masing gas }\end{array}$} \\
\hline & & $10-30$ & Bulanan & \\
\hline & & $>30$ & Bulanan & \\
\hline
\end{tabular}

c. Metode Key Gas

Tabel 10. Presentase Hasil Perhitungan Metode Key Gas

\begin{tabular}{c|ccccccc}
\hline \multirow{2}{*}{ TGL UJI } & \multicolumn{7}{c}{ KEY GAS } \\
\cline { 2 - 8 } & $\mathrm{H} 2 \%$ & $\mathrm{CO} \%$ & $\mathrm{CH}_{4} \%$ & $\mathrm{C}_{2} \mathrm{H}_{4} \%$ & $\mathrm{C}_{2} \mathrm{H}_{6} \%$ & $\mathrm{C}_{2} \mathrm{H}_{2} \%$ & TOTAL \\
\hline 09 Maret 2011 & 6.89 & 85.35 & 7.0 & 0.3 & 0.3 & 0 & 100 \\
25 Mei 2012 & 10.6 & 77.72 & 9.37 & 0 & 2.11 & 0.17 & 100 \\
28 Mei 2013 & 10.23 & 81.9 & 7.79 & 0 & 0 & 0 & 100 \\
\hline
\end{tabular}

\section{d. Metode Roger's Ratio}

Berdasarkan data hasil uji DGA Transformator II Gardu Induk Tanggul, maka dapat dianalisis sebagai berikut:

- $\quad$ Tanggal 9 Maret 2011

Tabel 11. Hasil Perhitungan dengan Roger's Ratio Tanggal 9 Maret 2011

\begin{tabular}{cccc}
\hline Fault Gas & Nilai & $\begin{array}{c}\text { Perbandingan Fault } \\
\text { Gas }\end{array}$ & Digid Kode \\
\hline $\mathrm{C}_{2} \mathrm{H}_{2}$ & 0 & $\mathrm{C}_{2} \mathrm{H}_{2} / \mathrm{C}_{2} \mathrm{H}_{4}$ & 0 \\
$\mathrm{C}_{2} \mathrm{H}_{4}$ & 2.23 & $0 / 2.23=0$ & \\
$\mathrm{CH}_{4}$ & 43.55 & $\mathrm{CH}_{4} / \mathrm{H}_{2}$ & 2 \\
$\mathrm{H}_{2}$ & 42.58 & $43.55 / 42.58=1.02$ & \\
$\mathrm{C}_{2} \mathrm{H}_{6}$ & 2.29 & $\mathrm{C}_{2} \mathrm{H}_{4} / \mathrm{C}_{2} \mathrm{H}_{6}$ & 0 \\
& & $2.23 / 2.29=0.97$ & \\
\end{tabular}

- Tanggal 25 Mei 2012

Tabel 12. Hasil Perhitungan dengan Roger's Ratio Tanggal 25 Mei 2012

\begin{tabular}{cccc}
\hline Fault Gas & Nilai & Perbandingan Fault Gas & Digid Kode \\
\hline $\mathrm{C}_{2} \mathrm{H}_{2}$ & 1.63 & $\mathrm{C}_{2} \mathrm{H}_{2} / \mathrm{C}_{2} \mathrm{H}_{4}$ & - \\
$\mathrm{C}_{2} \mathrm{H}_{4}$ & 0 & $1.63 / 0=$ tidak terdefinisi & \\
$\mathrm{CH}_{4}$ & 85.65 & $\mathrm{CH}_{4} / \mathrm{H}_{2}$ & 0 \\
$\mathrm{H}_{2}$ & 96.84 & $85.65 / 96.84=0.884$ & \\
$\mathrm{C}_{2} \mathrm{H}_{6}$ & 19.29 & $\mathrm{C}_{2} \mathrm{H}_{4} / \mathrm{C}_{2} \mathrm{H}_{6}$ & 0 \\
& & $0 / 19.29=4.44$ & \\
\hline
\end{tabular}


- $\quad$ Tanggal 28 Mei 2013

Tabel 13. Hasil Perhitungan dengan Roger's Ratio Tanggal 28 Mei 2013

\begin{tabular}{cccc}
\hline Fault Gas & Nilai & Perbandingan Fault Gas & Digid Kode \\
\hline $\mathrm{C}_{2} \mathrm{H}_{2}$ & 0 & $\mathrm{C}_{2} \mathrm{H}_{2} / \mathrm{C}_{2} \mathrm{H}_{4}$ & - \\
$\mathrm{C}_{2} \mathrm{H}_{4}$ & 0 & $0 / 0=$ tidak terdefinisi & \\
$\mathrm{CH}_{4}$ & 76.35 & $\mathrm{CH}_{4} / \mathrm{H}_{2}$ & 0 \\
$\mathrm{H}_{2}$ & 100.23 & $76.35 / 100.23=0.76$ & \\
$\mathrm{C}_{2} \mathrm{H}_{6}$ & 0 & $\mathrm{C}_{2} \mathrm{H}_{4} / \mathrm{C}_{2} \mathrm{H}_{6}$ & - \\
& & $0 / 0=$ tidak terdefinisi & \\
\hline
\end{tabular}

\section{e. Ratio $\mathrm{CO}_{2} / \mathrm{CO}$}

Berdasarkan Data hasil uji DGA Transformator II Gardu Induk Tanggul, maka dapat dianalisis sebagai berikut:

- $\quad$ Tanggal 9 Maret 2011

Berdasarkan hasil uji DGA pada tanggal ini diketahui bahwa nilai $\mathrm{CO}_{2}$ dan $\mathrm{CO}$ adalah 2421,52 ppm dan 529,13 ppm. Maka $\mathrm{CO}_{2} / \mathrm{CO}=2421 / 529,13=4,57$.

Indikasi Kegagalan: Pada ratio ini menunjukkan bahwa proses pemburukan sedang terjadi pada isolasi kertas akibat kegagalan high thermal dengan temperatur $>200^{\circ} \mathrm{C}$.

- $\quad$ Tanggal 25 Mei 2012

Berdasarkan hasil uji DGA pada tanggal ini diketahui bahwa nilai $\mathrm{CO}_{2}$ dan $\mathrm{CO}$ adalah 2646,84 ppm dan 709,69 ppm. Maka $\mathrm{CO}_{2} / \mathrm{CO}=2646,84 / 709,69=3,72$.

Indikasi Kegagalan: Pada ratio ini menunjukkan bahwa proses pemburukan sedang terjadi pada isolasi kertas akibat kegagalan high thermal dengan temperatur $>200^{\circ} \mathrm{C}$.

- $\quad$ Tanggal 28 Mei 2013

Berdasarkan hasil uji DGA pada tanggal ini diketahui bahwa nilai $\mathrm{CO}_{2}$ dan $\mathrm{CO}$ adalah 2979,85 ppm dan 803,09 ppm. Maka $\mathrm{CO}_{2} / \mathrm{CO}=2979,85 / 803,09=3,71$.

Indikasi Kegagalan: Pada ratio ini menunjukkan bahwa proses pemburukan sedang terjadi pada isolasi kertas akibat kegagalan high thermal dengan temperatur $>200^{\circ} \mathrm{C}$.

\section{f. Metode Duval's Triangle}

Berdasarkan data hasil uji DGA Transformator II Gardu Induk Tanggul, maka dapat dianalisis sebagai berikut:

- $\quad$ Tanggal 9 Maret 2011

Tabel 14. Presentase Gas dengan Metode Duval's Triangle 9 Maret 2011

\begin{tabular}{cccc}
\hline Fault Gas & Nilai & \% & Kondisi \\
\hline $\mathrm{CH} 4$ & 43,55 & $95,12 \%$ & $\mathrm{~K} 1$ \\
$\mathrm{C} 2 \mathrm{H} 4$ & 2,23 & $4,87 \%$ & $\mathrm{~K} 1$ \\
$\mathrm{C} 2 \mathrm{H} 2$ & 0 & $0 \%$ & $\mathrm{~K} 1$ \\
\hline
\end{tabular}

- $\quad$ Tanggal 25 Mei 2012

Tabel 15. Presentase Gas dengan Metode Duval's Triangle 25 Mei 2012

\begin{tabular}{cccc}
\hline Fault Gas & Nilai & \% & Kondisi \\
\hline $\mathrm{CH} 4$ & 85,65 & $98,13 \%$ & $\mathrm{~K} 1$ \\
$\mathrm{C} 2 \mathrm{H} 4$ & 0 & $0 \%$ & $\mathrm{~K} 1$ \\
$\mathrm{C} 2 \mathrm{H} 2$ & 1,63 & $1,86 \%$ & $\mathrm{~K} 1$ \\
\hline
\end{tabular}


- $\quad$ Tanggal 28 Mei 2013

Tabel 16. Presentase Gas dengan Metode Duval's Triangle 28 Mei 2013

\begin{tabular}{cccc}
\hline Fault Gas & Nilai & \% & Kondisi \\
\hline $\mathrm{CH} 4$ & 76,35 & $100 \%$ & $\mathrm{~K} 1$ \\
$\mathrm{C} 2 \mathrm{H} 4$ & 0 & $0 \%$ & $\mathrm{~K} 1$ \\
$\mathrm{C} 2 \mathrm{H} 2$ & 0 & $0 \%$ & $\mathrm{~K} 1$ \\
\hline
\end{tabular}

\section{g. Indikasi Kegagalan Hasil Analisis}

Hasil analisis menggunakan metode Key Gas mengindikasikan terjadi karbonasi kertas, munculnya formasi partikel karbon pada minyak secara meluas, perubahan warna pada isolasi kertas $\left(200^{\circ} \mathrm{C}\right)$, Roger's Ratio menunjukkan Thermal Fault temperature 150-300 ${ }^{\circ} \mathrm{C}$ melibatkan isolasi kertas yang akan menghasilkan $\mathrm{CO}$ dan $\mathrm{CO}_{2}$ (Tahun 2011), dan pada Ratio $\mathrm{CO}_{2} / \mathrm{CO}$ menunjukkan bahwa proses pemburukan sedang terjadi pada isolasi kertas akibat kegagalan high thermal dengan temperatur $>200^{\circ} \mathrm{C}$.

\subsection{Rekomendasi Tindakan Operasi}

a. Berdasarkan penelitian yang telah dilakukan, berikut adalah rekomendasi yang disarankan berdasarkan Metode TDCG

Tabel 17. Rekomendasi Tindakan Operasional Transformator II GI Tanggul

\begin{tabular}{|c|c|c|c|c|}
\hline \multirow[b]{2}{*}{$\begin{array}{c}\text { Kondisi } \\
1\end{array}$} & \multirow{2}{*}{$\begin{array}{l}\text { Tingkat TDCG } \\
\text { atau nilai } \\
\text { tertinggi dari } \\
\text { masing-masing } \\
\text { gas (dari tabel } \\
\text { diatas) }\end{array}$} & \multirow{2}{*}{$\begin{array}{c}\text { Tingkat } \\
\text { kenaikan } \\
\text { TDCG } \\
\text { (ppm } \\
\text { perhari) }\end{array}$} & \multicolumn{2}{|c|}{$\begin{array}{l}\text { Interval sampling dan tindakan } \\
\text { pengoperasian }\end{array}$} \\
\hline & & & $\begin{array}{l}\text { Interval } \\
\text { Sampling }\end{array}$ & Tindakan Pengoperasian \\
\hline \multirow{3}{*}{$\begin{array}{c}\text { Kondisi } \\
2\end{array}$} & \multirow{3}{*}{$\begin{array}{c}721-1920 \\
\text { ppm,atau nilai } \\
\text { tertinggi dari } \\
\text { masing-masing } \\
\text { Gas }\end{array}$} & $<10$ & $\begin{array}{c}\text { Tiga } \\
\text { bulanan }\end{array}$ & \multirow{3}{*}{$\begin{array}{l}\text { Perhatikan, analisis } \\
\text { penyebab masing- } \\
\text { masing gas }\end{array}$} \\
\hline & & $10-30$ & Bulanan & \\
\hline & & $>30$ & Bulanan & \\
\hline
\end{tabular}

Hasil analisis pada tabel 17 diatas diperoleh dari analisis dengan menggunakan Metode TDCG sesuai standar IEEE. Transformator berada dalam Kondisi 2 pada Tahun 2012 sebesar 913,1 ppm dan Tahun 2013 sebesar 979,67 (Nilai TDCG 721-1920 ppm, atau nilai tertinggi dari masing-masing gas) dan tingkat kenaikan TDCG ppm perhari $<10$ diperoleh dari perhitungan TDCG Generation Rate dengan hasil 0,18 ,maka rekomendasi interval sampling pengujian DGA adalah tiga bulanan dan rekomendasi tindakan pengoperasiannya adalah perhatian, lakukan analisis penyebab masing-masing gas.

b. Berdasarkan hasil analisis Ratio $\mathrm{CO}_{2} / \mathrm{CO}$, berikut adalah rekomendasi yang disarankan berdasarkan Metode Ratio $\mathrm{CO}_{2} / \mathrm{CO}$

Tabel 18. Rekomendasi Tindakan Operasi berdasarkan Ratio $\mathrm{CO}_{2} / \mathrm{CO}$

\begin{tabular}{|c|c|c|}
\hline Metode & Ratio & Rekomendasi Tindakan \\
\hline \multirow{4}{*}{$\mathrm{CO}_{2} / \mathrm{CO}$} & $<3$ & $\begin{array}{l}\text { Lakukan pengujian furan pada pengujian minyak selanutnya } \\
\text { untuk mengetahui seberapa besar tingkat penurunan kualitas } \\
\text { yang dialami isolasi kertas didalam transformator dana } \\
\text { berapa lama sisa umur isolasi kertas tersebut. }\end{array}$ \\
\hline & $3-<5$ & $\begin{array}{l}\text { Lakukan pengujian furan pada pengujian minyak selanutnya } \\
\text { untuk mengetahui seberapa besar tingkat penurunan kualitas } \\
\text { yang dialami isolasi kertas didalam transformator dana } \\
\text { berapa lama sisa umur isolasi kertas tersebut. }\end{array}$ \\
\hline & $<3$ & Normal Operasi \\
\hline & $>10$ & $\begin{array}{l}\text { Lakukan pengujian furan pada pengujian minyak selanutnya } \\
\text { untuk mengetahui seberapa besar tingkat penurunan kualitas } \\
\text { yang dialami isolasi kertas didalam transformator dana } \\
\text { berapa lama sisa umur isolasi kertas tersebut. }\end{array}$ \\
\hline
\end{tabular}


Hasil analisis pada tabel 18 diatas diperoleh dari analisis dengan menggunakan Metode Ratio $\mathrm{CO}_{2} / \mathrm{CO}$ dimana pada Tahun $2011=4,57$, Tahun $2012=3,72$ dan Tahun $2013=3,71$. Ketiga ratio tersebut masuk dalam ratio antara 3 sampai kurang dari 5 dengan rekomendasi tindakan operasional disarankan untuk dilakukan pengujian furan pada pengujian minyak selanjutnya.

\subsection{Pengujian Aplikasi Bantu Analisis DGA}

Tahap ini dilakukan pengujian menggunakan data pengujian Transformator II Gardu Induk Tanggul pada tanggal 28 Mei 2013.

Tabel 19. Data Hasil Uji DGA Tanggal 28 Mei 2013

\begin{tabular}{cccccccccc}
\hline No & Tgl Uji & $\mathbf{H}_{2}$ & $\mathbf{C O}$ & $\mathbf{C H}_{\mathbf{4}}$ & $\mathbf{C O}_{2}$ & $\mathbf{C}_{2} \mathbf{H}_{\mathbf{4}}$ & $\mathbf{C}_{2} \mathbf{H}_{\mathbf{6}}$ & $\mathbf{C}_{2} \mathbf{H}_{2}$ & TDCG \\
\hline 1 & 28 Mei 2013 & 100.23 & 803.09 & 76.35 & 2979.85 & 0 & 0 & 0 & 979.67
\end{tabular}

Berikut adalah tabel hasil Analisis Data Uji DGA GI Tanggul Tanggal 28 Mei 2013:

Tabel 20. Hasil Analisis Data Uji DGA GI Tanggul Tanggal 28 Mei 2013

\begin{tabular}{|c|c|c|}
\hline NO & METODE & ANALISIS \\
\hline 1 & TDCG & $\begin{array}{l}\text { TDCG bernilai } 979.67 \text { yang berarti TDCG pada level ini } \\
\text { menandakan komposisi gas sudah melebihi batas nilai normal. } \\
\text { Bila salah satu gas melebihi nilai batasan level harus di investigasi } \\
\text { dengan cepat. Lakukan tindakan untuk mendapatkan trending gas } \\
\text { dan kemungkinan transformator tersebut pernah mengalami } \\
\text { gannguan. }\end{array}$ \\
\hline 2 & KEY GAS & $\begin{array}{l}\text { Over Heating Cellulose, terjadi karbonasi kertas, munculnya } \\
\text { formasi partikel karbon pada minyak secara meluas, perubahan } \\
\text { warna pada isolasi kertas }\left(200^{\circ} \mathrm{C}\right) \text { ataupun penggabungan metal } \\
\left(>100^{\circ} \mathrm{C}\right) \text {. trafo mengalami overload, terjadi masalah pada sistem } \\
\text { pendingin, kontak yang jelek pada sisi terminal incoming, atau } \\
\text { kontak yang jelek pada tap charger. }\end{array}$ \\
\hline 3 & RATIO ROGER'S & $\begin{array}{l}\text { Tidak terdefinisi, kombinasi kode tidak termasuk dalam kombinasi } \\
\text { kode Roger's Ratio atau berada diluar kriteria analisis. }\end{array}$ \\
\hline 4 & $\mathrm{RATIO} \mathrm{CO}_{2} / \mathrm{CO}$ & $\begin{array}{l}\text { Pada ratio ini menunjukkan bahwa proses pemburukan sedang } \\
\text { terjadi pada isolasi kertas akkibat kegagalan high thermal dengan } \\
\text { temperatur }>200^{\circ} \mathrm{C} \text {. }\end{array}$ \\
\hline 5 & $\begin{array}{l}\text { DUVAL'S } \\
\text { TRIANGLE }\end{array}$ & $\begin{array}{l}\text { Tidak terdefinisi, konsentrasi } \mathrm{C} 2 \mathrm{H} 2, \mathrm{CH} 4 \text { dan } \mathrm{C} 2 \mathrm{H} 2 \text { masih berada } \\
\text { dibawah level kriteria evaluasi segitiga Duval. }\end{array}$ \\
\hline
\end{tabular}

\section{a. Pengujian Metode TDCG}

Pengujian dengan metode TDCG merupakan pengujian yang paling utama dilakukan. Hasil pengujian menggunakan metode TDCG pada penelitian ini dapat dilihat pada gambar 4 berikut ini.

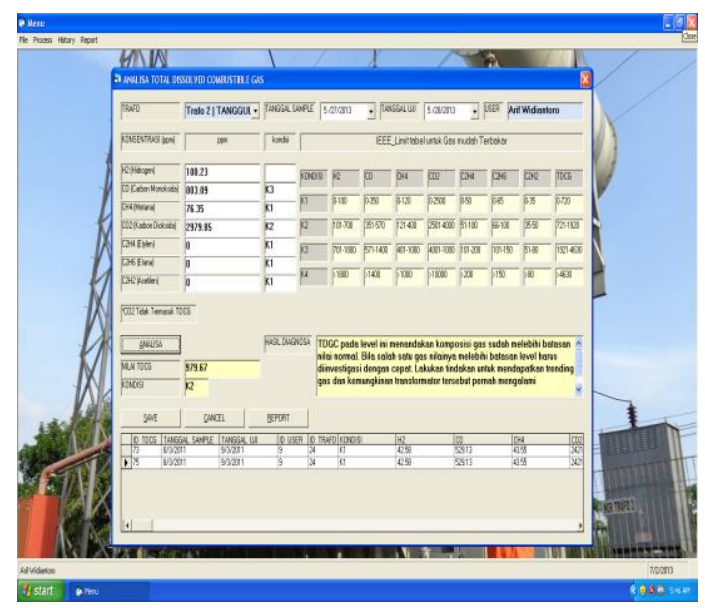




\section{b. Pengujian Penjadwalan Sampel Minyak}

Berdasarkan pengujian penjadwalan sampel minyak diperoleh rentan tanggal pengujian pertama dan kedua adalah 368 hari dan selisih TDCG pengujian kedua dengan pertama adalah 66,57. Sehingga TDCG Generation Ratenya adalah $66,57 / 368=0,18$. Dari perhitungan dengan mengacu pada tabel interval sampling dan tindakan operasi berdasarkan TDCG dapat diketahui bahwa jadwal pengambilan sampel minyak selanjutnya adalah tiga bulanan. Pengujian penjadwalan sampel minyak pada penelitian ini dapat dilihat pada gambar 5 berikut.

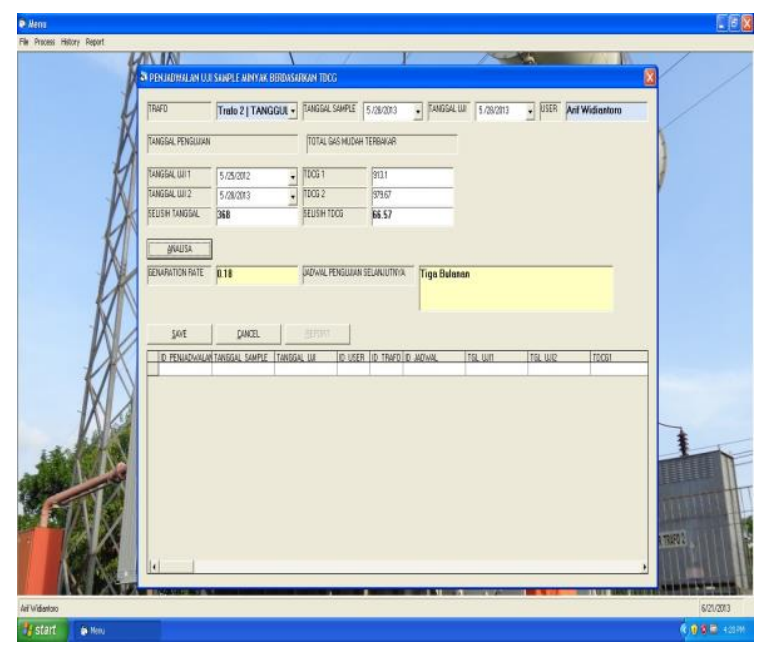

Gambar 5. Tampilan Pengujian Penjadwalan Sampel Minyak

\section{c. Pengujian Metode Key Gas}

Berdasarkan hasil pengujian dengan metode key gas dapat diketahui bahwa gas kunci adalah $\mathrm{CO}$ atau karbon monoksida sebesar $803 \mathrm{ppm}$ atau $82 \%$. Hasil diagnosa menunjukkan terjadinya karbonasi kertas, munculnya formasi partikel karbon pada minyak secara meluas, perubahan warna pada isolasi kertas $\left(200^{\circ} \mathrm{C}\right)$ ataupun penggabungan metal $\left(>100^{\circ} \mathrm{C}\right)$, trafo mengalami overload, terjadi masalah pada sistem pendingin, kontak yang jelek pada sisi terminal incoming atau tap changer.

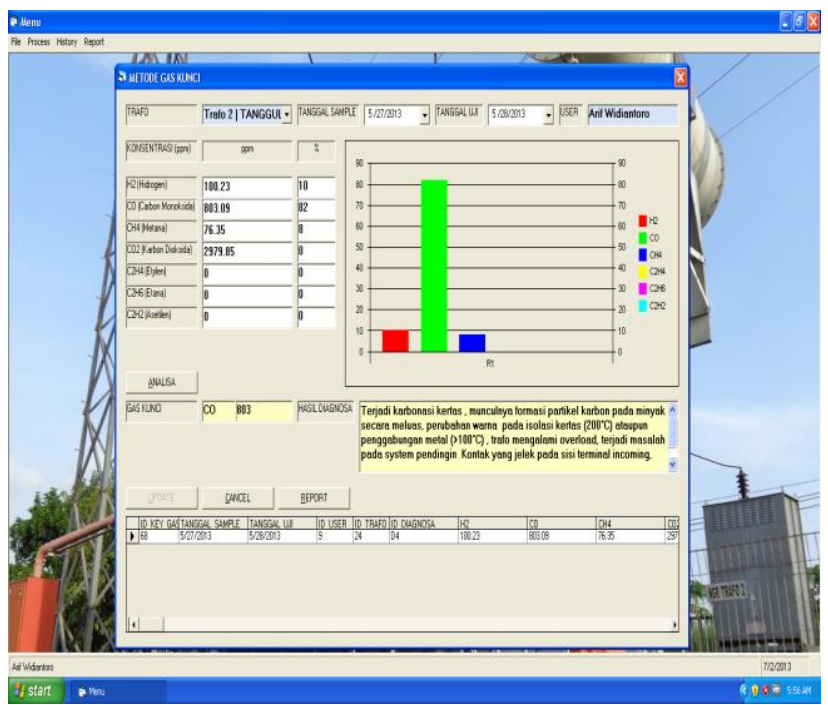

Gambar 6. Tampilan Pengujian Key Gas 


\section{d. Pengujian Metode Ratio Roger's dan Ratio $\mathrm{CO}_{2} / \mathrm{CO}$}

Berdasarkan hasil pengujian dengan metode Ratio Roger's pada penelitian ini diperoleh bahwa kombinasi kode (-,0,-) tidak termasuk dalam kombinasi kode Roger's Ratio atau berada diluar kriteria analisis. Sedangkan hasil pengujian dengan metode Ratio $\mathrm{CO}_{2} / \mathrm{CO}$ dapat diketahui bahwa nilai ratio sebesar 3,71. Indikasi Kegagalan pada ratio ini menunjukkan bahwa proses pemburukan sedang terjadi pada isolasi kertas akibat kegagalan high thermal dengan temperature $>200^{\circ} \mathrm{C}$.

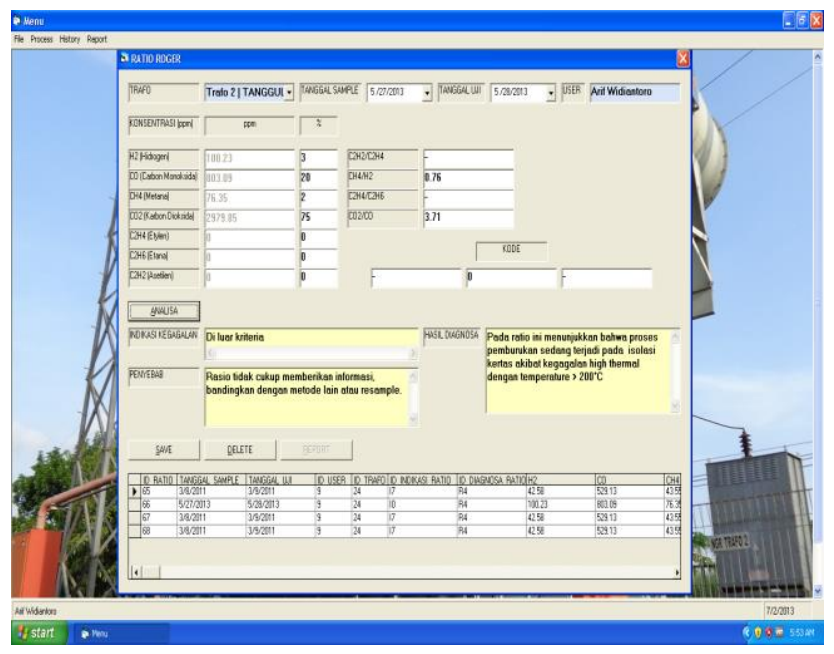

Gambar 7. Tampilan Pengujian Menu Roger's Ratio dan Ratio $\mathrm{CO}_{2} / \mathrm{CO}$

\section{e. Pengujian Metode Duval's Triangle}

Berdasarkan pengujian menu metode Duval's Triangle yang telah dilakukan pada penelitian ini diketahui bahwa analisis tidak terdefinisi, konsentrasi $\mathrm{C}_{2} \mathrm{H}_{2}, \mathrm{CH} 4$ dan $\mathrm{C}_{2} \mathrm{H}_{4}$ dalam kondisi 1 yaitu masih berada dibawah level kriteria evaluasi Segitiga Duval minimal salah satu gas hidrokarbon dalam kondisi 3. Setelah dilakukan analisis terhadap data hasil uji DGA Transformator II Gardu Induk Tanggul pada tanggal 28 Mei 2013 dengan menggunakan analisis manual maupun dengan menggunakan aplikasi analisis DGA dapat disimpulkan bahwa aplikasi telah berjalan sesuai dengan yang diharapkan. Hal ini ditunjukkan dengan hasil analisis yang telah sesuai dengan analisis manual yang telah dilakukan.

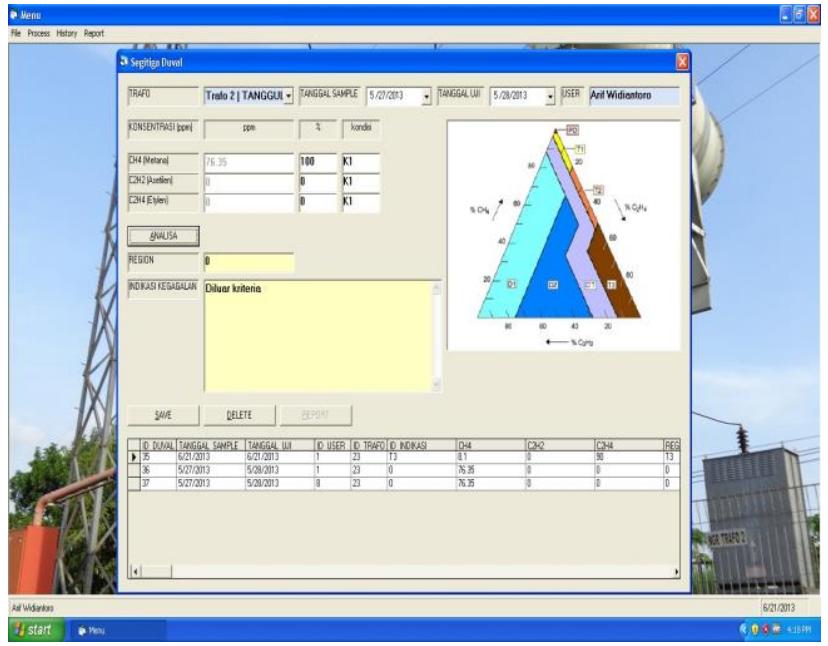

Gambar 8. Tampilan Pengujian Metode Duval's Triangle 


\section{KESIMPULAN}

Berdasarkan penelitian yang telah dilakukan, maka dapat disimpulkan beberapa hal sebagai berikut:

a. Berdasarkan analisis dengan metode TDCG pada tahun 2012 dan 2013 Transformator II Gardu Induk Tanggul dalam kondisi 2. TDCG pada level ini menandakan komposisi gas sudah melebihi batasan nilai normal. Bila salah satu gas nilainya melebihi batasan level harus diinvestigasi dengan cepat. Lakukan tindakan untuk mendapatkan trending gas dan kemungkinan transformator tersebut pernah mengalami gangguan.

b. Berdasarkan analisis dengan metode Key Gas pada tahun 2011, 2012 dan 2013 gas kunci adalah CO dengan konsentrasi pada tahun 2011 sebesar 85,35\%, tahun 2012 sebesar $77.72 \%$ dan tahun 2013 sebesar 81,9\%. Gas kunci CO mengindikasikan kemungkinan yabg terjadi adalah overheating cellulosa, terjadi karbonasi kertas , munculnya formasi partikel karbon pada minyak secara meluas, perubahan warna pada isolasi kertas $\left(200^{\circ} \mathrm{C}\right)$ ataupun penggabungan metal $\left(>100^{\circ} \mathrm{C}\right)$, trafo mengalami overload, terjadi masalah pada sistem pendingin, kontak yang jelek pada sisi terminal incoming atau tap changer.

c. Berdasarkan analisis dengan metode Roger's Ratio tahun 2011 diperoleh indikasi kegagalan Thermal fault temperature 150-300 ${ }^{\circ} \mathrm{C}$, Overheating pada inti transformator. Masalah ini kemungkinan melibatkan isolasi kertas yang akan menghasilkan $\mathrm{CO}$ dan $\mathrm{CO}_{2}$.

d. Berdasarkan analisis dengan metode ratio $\mathrm{CO}_{2} / \mathrm{CO}$, ratio pada Tahun $2011=4,57$, Tahun $2012=$ 3,72 dan Tahun $2013=3,71$. Ketiga ratio tersebut masuk dalam ratio antara 3 sampai kurang dari 5 maka indikasi kegagalan yang terjadi adalah proses pemburukan sedang terjadi pada isolasi kertas akibat kegagalan high thermal dengan temperatur $>200^{\circ} \mathrm{C}$.

e. Pada analisis dengan metode Duval's Triangle diperoleh bahwa hasil analisis tidak terdefinisi, karena konsentrasi $\mathrm{C}_{2} \mathrm{H}_{2}, \mathrm{CH}_{4}$ dan $\mathrm{C}_{2} \mathrm{H}_{4}$ masih berada dibawah level kriteria evaluasi Segitiga Duval.

Adapun saran pada penelitian ini yaitu jadwal pengambilan sampel minyak sebaiknya dilakukan sesuai dengan perhitungan yang mengacu pada tabel interval sampling dan tindakan operasi berdasarkan TDCG agar kondisi transformator dapat terus terpantau.

\section{REFERENSI}

[1] Alstom Grid Technical Institute, 2011. Transformer Oil Testing, France: Alstom.

[2] PLN (Persero) P3B JB, PT. 2003. Panduan Pemeliharaan Transformator Tenaga. Jakarta: PT. PLN (Persero) P3B Jawa Bali.

[3] United States Department of the Interior Bureau of Reclamation. 2000. Transformer Maintenance, Colorado: United States Department of the Interior.

[4] Winarno, E. 2013. Belajar Pemrograman VB6 Dalam Sekejap. Jakarta: PT Elex Media Komputindo.

[5] Wikipedia., 2017, Microsoft Access [online] Tersedia di: http://id.wikipedia.org/wiki/Microsoft_Access. Diakses pada 7 Mei 2013. 


\section{BIOGRAFI PENULIS}

$\begin{aligned} & \text { Ir. Misto, M.Si merupakan dosen sekaligus peneliti dari Universitas Jember yang dalam } \\ & \text { risetnya fokus pada bidang optoelektronika dan instrumentasi. }\end{aligned} \mid \begin{aligned} & \text { Haryono, Lahir di Situbondo, 15 April 1993. Pada tahun 2013, Penulis menempuh } \\ & \text { pendidikan Strata 1 (S-1) Jurusan Teknik Elektro Universitas Muhammadiyah Jember, dan } \\ & \text { berhasil menyelesaikan penelitian dengan judul "Pengembangan Prototipe Pemadam Api } \\ & \text { dan Penghisap Asap Otomatis pada Sistem Deteksi Kebakaran Dini Berbasis Arduino } \\ & \text { Mega 2560" sebagai syarat untuk memperoleh gelar Sarjana Teknik. Saat ini penulis } \\ & \text { sedang menempuh pendidikan Strata 2 (S-2) Jurusan Teknik Elektro Universitas Jember } \\ & \text { dan fokus dalam penelitian tesis pada bidang elektronika Medis. }\end{aligned}$

